Open Access

\title{
Causality between bank's major activities and economic growth: evidences from Pakistan
}

Saba Mushtaq

\author{
Correspondence: \\ sabamushtaq238@gmail.com \\ Karachi University Business School, \\ University of Karachi, Karachi, \\ Pakistan
}

\begin{abstract}
Background: Banking is an important sector of Pakistan's economy. It is general consideration that bank's major activities saving and lending have positive impact on economic growth. So the aim of this study is to investigate this consideration and also investigate that either growth led deposits and credits, or deposit and credits led growth means the purpose of this study is to investigate the direction of this relationship.
\end{abstract}

Methods: Johansen test of Co-integration and Granger Causality is employed by using time series data of Pakistan from 1961 to 2013.

Results: The results show that two major activities of banking sector that are saving and lending don't have any long run or short run causality towards economic growth so the general consideration of positive impact of these activities proved wrong in case of Pakistan. However there is unidirectional causality running from GDP growth to credit provided by banking sector which shows that economic prosperity or economic growth will have a major impact on lending activities of banks meaning that demand following hypothesis is true for Pakistan in case of GDP and Bank's credit or we can say that growth led Bank's credit in Pakistan.

Conclusions: Hence Government and central bank should make policies by keeping this fact in consideration that bank's two major activities that are saving and lending does not have impact on GDP growth. There might be other factors which influence economic growth of Pakistan more than banking sector these activities, which can be bank's profitability, human resource, technology, infrastructure and other sectors of the economy. However GDP growth affects bank's lending activities so during high economic growth year central bank and private bank's management should introduce easy loans for businesses and industries and during poor economic growth years personal loan's new schemes should be introduce by banks.

Keywords: Granger Causality, Cointegration, Economic Growth, Bank deposits, Bank's credit

JEL classification: C22, C32, F43, G21, G24 


\section{Background}

Banking sector is considered an important sector for economic growth there are two basic activities done by banks one is attract customer to save their savings (by giving certain amount called interest) and it is known as bank deposits and other is lending activities that is to provide loans for investment or personal uses and take interest on them. Government of Pakistan and Central bank make different rules and regulations for banks with the aim to increase economic growth in long run. These rules and instructions also include increase in deposits with banks and provide loans on easy terms and condition. Central bank instructs and orders banks to introduce different types of accounts to attract savers to open and keep their savings in bank accounts with the perception that in long run it will contribute to enhance economic growth.

Banks uses these deposits to further lend money so it is compulsory for Government to know the fact that which activity of banking sector has cointegration with economic growth so Government can make effective policies in future for the prosperity of country.

Banking sector is considered as one of the major industry of Pakistan's economy and in government policies government always tries to make policies in order to accelerate banking sector's activities.

But Pakistan is a country in which most of the banks are private and only few banks are owned by government. So if private banks will earn profit then this will not be beneficial for government. In this case only bank's activities are the part of private banks that can be part of interest for government because it is considered to have effect on economic growth so because of this reason I select Pakistan as a country for my study.

Lack of data availability was a big limitation for this study so I tried to include the time period in which data was available for all three variables.

Bank's activities (that are deposits and lending) are the key things that will not only affect economy but also will affect the population and government of the country so the purpose of this study is to investigate the direction between these two activities and economic growth and to know the fact that either this relationship is unidirectional or bidirectional.

There has been done a lot of work in economic literature about banking sector but there are very few studies that considered specifically deposits or credits side of banking sector and there causal directional relationship with economic growth but In Pakistan no one considered causal relationship specifically between pooling and lending activities of bank and economic growth but combine studies have been done by using bank deposit and bank's credit as a determinant of GDP or by keeping credits or deposits of banks as proxy of financial development with other additional variables. So this study will provide a guideline to policy makers that whether it is realistic to consider bank deposit and bank's provided loans to increase the economic growth in Pakistan and also this study will tell to bank managements that either GDP growth has any short run or long run impact on banking sector's these activities. Secondly according to general consideration bank deposits and lending activities have positive impact on economic growth but this study concludes opposite results so the purpose is to investigate the real scenario that is also the base for narrow selection of bank's these two activities.

The paper is organized as Introduction this section, section 2 presents review of literature, sections 3 presents data, methodology and results and section 4 concludes the paper. 


\section{Review of literature}

Patrick (1966) first discussed the causality direction as demand-following and supply leading hypothesis. In 1988 Mckinnon buttressed this statement.

a) Demand-following hypothesis (growth led finance):

When because of economic growth, demand for financial services will increase and will result financial development. It is Demand-following hypothesis.

b) Supply-Leading hypothesis (finance led growth)

According to this hypothesis if there will be more activities of financial institutions then this will lead towards increase in productive capacity of a particular economy. And in this hypothesis causal relationship runs from financial development to growth.

\section{Studies related to bank's deposits and economic growth}

Researchers concluded different result for different countries. Some researchers concluded that there is no relationship between bank's deposits and economic growth such as Kumar and Chauhan (2015) did study in India by using cointegration and granger causality and concluded that saving deposits with commercial bank does not granger cause GDP of India.

However according to some researcher there is unidirectional causal relationship running from economic growth to bank's saving.

Liang and Reichert (2006) found causal relationship between financial sector development and economic growth of developing and advance countries. They concluded that causality run from economic development to financial sector development. However this causal relationship is strong in case of developing countries as compare to advance countries.

Tahir (2008) did study in Pakistan and concluded that there is unidirectional causality running from economic development to financial development both in short run and long run. Real per capita GDP was used as a proxy of economic development while ratio of domestic credit to GDP, total capital formation to GDP, weighted average savings interest rate minus current GDP deflator and GDP deflator were used for financial development.

Awdeh (2012) did study in Lebanon and concluded that there is one way causality running from economic growth to banking or financial sector so this study supports demand following or growth led finance hypothesis.

Some researchers believe that there is bidirectional relationship between bank's deposits and economic growth.

Aurangzeb (2012) concluded that banking sector does a significant contribution in the economic growth of Pakistan by using regression and granger causality method. Regression result indicates that deposit, investment, advances, profitability and interest earnings have positive significant impact on economic growth of Pakistan. He further found that there is bidirectional causality between deposits, advances and profitability with economic growth while unidirectional causality running from investment and interest earning to economic growth of Pakistan.

Following studies concluded that bank's deposits have significant positive impact on economic growth. 
Babatunde et al. (2013) did study in Malaysia and concluded that profitability loan and advances have positive significant impact on economic development while deposits and assets of banks does not have any impact on economic development in Malaysia.

Sharma and Ranga (2014) did study in India and concluded that saving deposits with commercial banks have positive significant impact on GDP of India.

\section{Studies related to bank's credit and economic growth}

According to some researchers there is positive significant impact of bank's credit on economic growth.

Korkmaz (2015) did study on 10 European countries and concluded that domestic credit provided by banking sector have effect on economic growth.

Iwedi Marshal et al. (2015) did study in Nigeria and found strong positive correlation between bank;s credit and GDP.

Nwakanma et al. (2014) concluded that there is significant long run relationship between bank's credit to private sector and economic growth in Nigeria but without significant level of causality.

Osman (2014) investigated the impact of private sector credit on the economic growth of Saudi Arabia using ARDL model and concluded that there is long run and short run relationship between private sector credit and economic growth of Saudi Arabia. Moreover commercial bank's credit to private sector will contribute in the economic growth of Saudi Arabia.

Emecheta and Ibe (2014) did study in Nigeria using Vector Autoregressive technique and concluded that there is positive and significant relationship between bank credit to private sector, broad money and economic growth.

However following studies concluded that there is unidirectional causality running from economic growth to bank's credit.

Onuorah and Ozurumba (2013) did study in Nigeria and concluded that Banks credits does not granger cause GDP but GDP have effect on Bank's credit. He further concluded that there is short run relationship between Bank credits and GDP.

Marshal et al. (2015) found the causal relationship between banking sector credit and economic growth in Nigeria and concluded that there is unidirectional relationship running from GDP to banking sector credit.

These studies found unidirectional causal relationship running from bank's credit to economic growth.

Caporale et al. (2009) did study about ten new EU member countries by using granger causality test and concluded that there is unidirectional causal relationship running from financial development to economic growth in ten new EU member countries. Credit to private sector and interest rate margin to economic growth variable have been used as a proxy of financial development.

According to Obradovic and Grbic (2015) economic growth contributes to financial deepening process. They concluded that there is unidirectional causality running from private enterprise credit to GDP and household credit to GDP, to economic growth of Serbia. Moreover according to them there is bidirectional causal relationship between the share of bank credit to non-financial private sector in total domestic credit and growth rate of economy. 
Alkhuzaim (2014) used cointegration and granger causality techniques and concluded that there is positive long run relationship between financial development indicators and GDP growth rate in Qatar. According to him in long run there is unidirectional causal relationship running from domestic credit provided by the bank sector to GDP growth while in short run direction of causality is opposite. Further he concluded that there is no causal relationships exist between bank credits to private sector and GDP growth rate in long run or short run.

\section{Data, methodology and results}

The basic purpose of this study was to investigate the causal relationship between banking sector two main activities (that is bank deposits and credits provided by banking sector) and GDP growth of Pakistan. The data was collected from World Bank development indicator's various issues. Annual time series data of Pakistan was used from the period 1961 to 2013.

Johansen and Juselius (1990) maximum likelihood estimation model is used to determine the cointegration between the variables. This model only describes the existence of cointegration between the variables but unable to describe the direction of causality. For this purpose Granger causality and VECM models have been use to determine direction of causality in short and long run. The mathematical form of the basic model is as under

$$
\begin{aligned}
& \text { LnEconomicGrowtht }=\beta_{0}+\beta 1 \text { Ln BankDeposit }{ }_{t}+\varepsilon t \quad(\text { Model 1) } \\
& \text { LnEconomicGrowtht }=\beta_{0}+\beta 1 \text { Ln Bank'sCredit }{ }_{t}+\varepsilon t \quad(\text { Model 2) }
\end{aligned}
$$

Bank deposits \% of GDP, GDP growth (annual \%) and Bank credit to private sector with GDP (annual \%) has been used as a proxy of Bank deposit, Economic growth and Bank's credit respectively. Coefficient $\beta 1$ in both models is expected to have positive sign in short run and long run.

\section{Unit root test (Augmented Dickey Fuller test)}

In order to use cointegration model the first condition is that all the variables must be integrated at the same order, for this purpose Augmented Dickey Fuller (ADF) unit root test is employed.

The equation of $\mathrm{ADF}$ test can be presented as under. By adding lagged values this test checks the serial correlation.

$$
\Delta Y_{t}=\beta_{0}+\gamma_{t}+\beta_{1} Y_{t-1}+\sum_{i=1}^{n} \delta_{l} \Delta Y_{t-i}+\varepsilon_{t}
$$

Where $\varepsilon_{t}$ is white noise error term and $\Delta Y_{t}=Y_{t}-Y_{t-1}$

The results of both models, Model 1 and Model 2 are presented in the Table 1. From the results we can conclude that all the variables are non-stationary or have unit root at their levels but after first difference they became stationary.

So this result directs us towards the test of cointegration because condition of cointegration has been fulfilled because variables are integrated at the same order for both models. 
Table 1 Result of Unit Root Test (ADF test statistics)

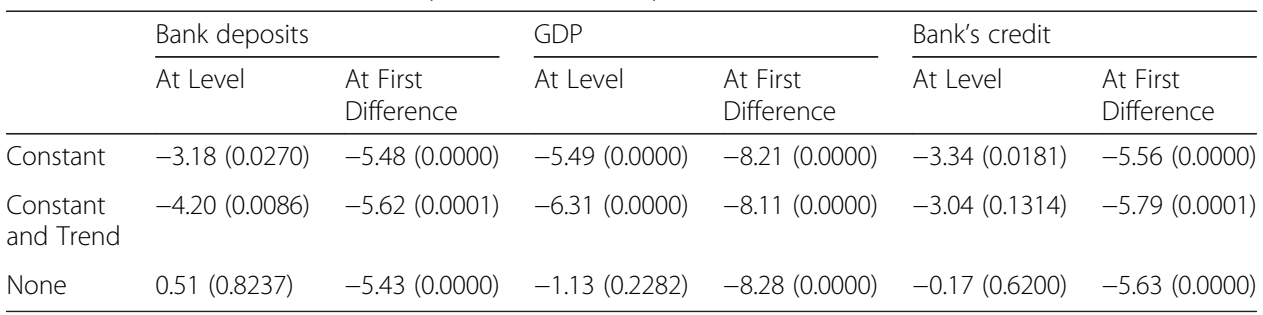

Note: Figures in parenthesis are $\mathrm{p}$ values

\section{Lag length selection}

For lag selection in both models all crieteria that are LR test statistics,Final Prediction error,A/C Akaike information criterion and Hannan-Quinn information criterion suggested lag 4 for model 1 and lag 2 for model no 2. Results for Model no 1 is in Table 2 and results for Model no 2 is in Table 3.

This lag length selection will use for both cointegration and granger causality.

\section{Cointegration test}

For cointegrtion following unrestricted VAR model have to estimate:

$$
Y_{t}=A_{0}+\sum_{i=1}^{n} A i Y_{t-i}+\mathrm{E}_{t}
$$

Where $Y_{t}$ is $\mathrm{n} \times 1$ vector of variable having unit root that is GDP growth and Bank deposit for Model one and GDP growth and Bank credit in second model.

$A_{0}$ is vector of contant, $\mathrm{n}$ is lag no, $\mathrm{Ai}$ is estimated parameter's $3 \times 3$ matrix and $E t$ is error term.

If variables are cointegrated then VECM model will be employed to find the short run and long run causality instead of unrestricted VAR model.

Table 2 Lag order selection criteria (bank deposits and GDP) Model no 1

\begin{tabular}{llllll}
\hline Lag & LogL & LR & FPE & AIC & HQ \\
\hline 0 & -199.5701 & NA & 63.87653 & 9.832687 & 9.863125 \\
1 & -176.3837 & 42.97968 & 25.06655 & 8.896765 & 8.988080 \\
2 & -169.5563 & 11.98952 & 21.87906 & 8.758844 & 8.911037 \\
3 & -165.7950 & 6.238218 & 22.23103 & 8.770489 & 8.983558 \\
4 & -158.5610 & $11.29216^{\mathrm{a}}$ & $19.13468^{\mathrm{a}}$ & $8.612731^{\mathrm{a}}$ & $8.886677^{\mathrm{a}}$ \\
5 & -157.3654 & 1.749616 & 22.21350 & 8.749533 & 9.084356 \\
6 & -154.9377 & 3.315858 & 24.42833 & 8.826231 & 9.221931 \\
7 & -153.3333 & 2.034944 & 28.17479 & 8.943086 & 9.399663 \\
8 & -148.2550 & 5.945266 & 27.68736 & 8.890488 & 9.407942 \\
9 & -139.8924 & 8.974505 & 23.44999 & 8.677678 & 9.256009 \\
10 & -138.8030 & 1.062854 & 28.72958 & 8.819658 & 9.458865 \\
11 & -133.0830 & 5.022457 & 28.59181 & 8.735754 & 9.435839 \\
12 & -131.0694 & 1.571579 & 34.88322 & 8.832652 & 9.593614 \\
\hline
\end{tabular}

$L R$ sequential modified LR test statistic (each test at $5 \%$ level), FPE Final prediction error, AIC Akaike information criterion, $H Q$ Hannan-Quinn information criterion 
Table 3 Lag order selection criteria (BCPS and GDPG) Model no 2

\begin{tabular}{|c|c|c|c|c|c|}
\hline$\underline{\text { Lag }}$ & LogL & LR & FPE & AIC & $\mathrm{HQ}$ \\
\hline 0 & -237.2910 & NA & 59.81376 & 9.766978 & 9.796275 \\
\hline 1 & -214.1747 & 43.40201 & 27.42005 & 8.986722 & 9.074610 \\
\hline 2 & -206.7534 & $13.32804^{\mathrm{a}}$ & $23.87301^{\mathrm{a}}$ & $8.847077^{a}$ & $8.993558^{a}$ \\
\hline 3 & -202.8392 & 6.709956 & 24.01703 & 8.850582 & 9.055654 \\
\hline 4 & -201.3285 & 2.466519 & 26.70533 & 8.952184 & 9.215849 \\
\hline
\end{tabular}

Where

$$
\begin{gathered}
\Delta Y_{t}=A 0+\sum_{i=1}^{n-1} \phi i \Delta Y_{t-i}+\beta Y_{t-1}+\mathrm{E}_{t} \\
\phi=-\sum_{i=1}^{n-1} A_{i} \text { And } \beta=\sum_{i=1}^{n} A_{i-l}
\end{gathered}
$$

Where I is identity matrix $(\mathrm{n} \times \mathrm{n})$ and $\Delta$ is difference operator.

Trace test and Maximum Eigen value test of Johansen and Juselius (1990) have been used.

\section{Model no 1}

Null hypothesis = no cointegration between bank deposit and economic growth

Alternative hypothesis = existence of cointegration between bank deposit and economic growth

\section{Model no 2}

Null hypothesis $=$ no cointegration between bank's credit and economic growth

Alternative hypothesis = existence of cointegration between bank's credit and economic growth

Results of cointegration for both models are in Table 4.

Cointegration result for model no 1 shows that trace statistics and Max Eigen statistics are less than their corresponding $5 \%$ critical values and p value is more than $5 \%$ so we can reject Alternative and can accept null hypothesis that no cointegration exist between bank deposit and economic growth.

Cointegration results for model no 2 shows that trace statistics and Max Eigen statistics are more than their corresponding $5 \%$ critical values and p values are less than $5 \%$ so we can reject null hypothesis and can accept alternative hypothesis that there is cointegration between bank's credit and economic growth.

\begin{tabular}{|c|c|c|c|c|c|c|c|c|c|}
\hline \multirow[b]{3}{*}{$\mathrm{HO}$} & \multirow[b]{3}{*}{$\mathrm{H} 1$} & \multicolumn{4}{|c|}{ Model no 1} & \multicolumn{4}{|c|}{ Model no 2} \\
\hline & & \multicolumn{2}{|l|}{ Trace } & \multicolumn{2}{|c|}{ Max Eigen } & \multicolumn{2}{|l|}{ Trace } & \multicolumn{2}{|c|}{ Max Eigen } \\
\hline & & Statistic & Critical value & Statistic & Critical value & Statistic & Critical value & Statistic & Critical value \\
\hline$r=0$ & $r \geq 1$ & 13.633 & 15.49 & 8.36 & 14.26 & 34.14 & 15.49 & 19.40 & 14.26 \\
\hline
\end{tabular}

Table 4 Results of cointegration 
Table 5 Long run Causality

\begin{tabular}{|c|c|c|c|}
\hline Causality & ECMt-1 & T-statistics & $P$-value \\
\hline Long run causality from bank's credit to GDP & -0.1416 & -1.4627 & 0.1507 \\
\hline Long run causality from GDP to bank's credit ${ }^{a}$ & -0.3045 & -4.3841 & 0.0001 \\
\hline
\end{tabular}

\section{Granger causality test}

In order to find the direction of causality, granger causality (1960) test has been employed because cointegration test does not tell about direction. Granger causality test used past value of a variable $\mathrm{X}$ in order to forecast second variable $\mathrm{Y}$ and shows result in a form $\mathrm{X}$ ganger cause $\mathrm{Y}$.

\section{Model no 1}

$$
\begin{aligned}
& \Delta \text { LnEconomicGrowth }_{t}=\sum_{i=1}^{n} \beta_{11} \text { LnEconomicGrowth }_{t-1}+\sum_{j=1}^{n} \beta_{12} \text { LnBankDeposit }_{t-j}+\mathrm{E}_{1 t} \\
& \Delta \text { LBankDeposit }_{t}=\sum_{j=1}^{n} \beta_{21} \text { LnBankDeposit }_{t-1}+\sum_{i=1}^{n} \beta_{22} \text { LnEconomicGrowth }_{t-j}+\mathrm{E}_{2 t}
\end{aligned}
$$

\section{Model no 2}

$$
\begin{aligned}
& \Delta \text { LnEconomicGrowth }_{t}=\sum_{i=1}^{n} \beta_{11} \text { LnEconomicGrowth }_{t-1}+\sum_{j=1}^{n} \beta_{12} \text { LnBank }^{\prime} \text { Credit }_{t-j}+\mathrm{E}_{1 \mathrm{t}} \\
& \Delta \text { LBank'sCredit }_{t}=\sum_{j=1}^{n} \beta_{21} \text { LnBank'sCredit }_{t-1}+\sum_{i=1}^{n} \beta_{22} \text { LnEconomicGrowth }_{t-j}+\mathrm{E}_{2 t}
\end{aligned}
$$

Where $\mathrm{I}$ and $\mathrm{j}$ is lag lengths

Model no 1: Granger Test Pairwise

\begin{tabular}{llll}
\hline Null Hypothesis: & Obs & F-Statistic & Prob. \\
\hline GDPG does not Granger Cause BD & 49 & 2.13723 & 0.0940 \\
BD does not Granger Cause GDPG & & 1.49928 & 0.2207 \\
\hline
\end{tabular}

Note: GDPG economic growth, $B D$ bank deposits

Model no 2: Granger Test Pairwise

\begin{tabular}{llll}
\hline Null Hypothesis: & Obs & F-Statistic & Prob. \\
\hline GDPG does not Granger Cause BCPS & 51 & 4.13272 & 0.0224 \\
BCPS does not Granger Cause GDPG & & 2.43007 & 0.0993 \\
\hline
\end{tabular}

Note: GDPG economic growth, BCPS Bank's credit

Table 6 Short run Causality

\begin{tabular}{lcr}
\hline Causality & Wald test chi square value & $P$-value \\
\hline $\mathrm{D}(\text { LnBank's Credit }(-1))^{\mathrm{b}}$ & 1.2353 & 0.5392 \\
$\mathrm{D}(\operatorname{LnGDP}(-1))^{\mathrm{a}}$ & 8.1070 & 0.0174
\end{tabular}

${ }^{\mathrm{a}}$ LM Test $=0.5496$ (Prob of chi-square), Heteroskedasticity test $=0.23$ (prob of chi square), Jarque-Bera stat $=1.42(0.49 \mathrm{prob})$ ${ }^{b}$ LM Test $=0.2067$ (Prob of chi-square), Heteroskedasticity test $=0.3354$ (prob of chi square), Jarque-Bera stat $=2.04(0.35$ prob) 


\section{Vector Error Correction Model (VECM)}

According to Engel and Granger (1969) if variables are cointegrated then to analyze causality VECM vector error correction model will be use. This will analyze both long and short term causality with direction. The following VAR framework will be used to estimate VECM.

\section{Model no 1}

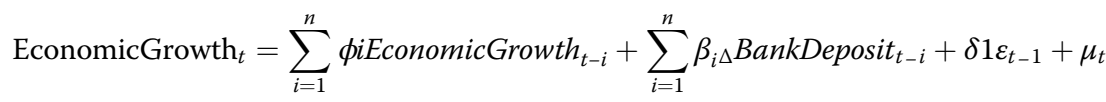

$$
\begin{aligned}
& \text { BankDeposit }_{t}=\sum_{j=1}^{p} \phi j \text { BankDeposit } t_{t-j}+\sum_{j=1}^{p} \beta_{j \Delta} \text { EconomicGrowth }_{t-1}+\delta 2 \varepsilon_{t-1}+\mu_{t}
\end{aligned}
$$

\section{Model no 2}

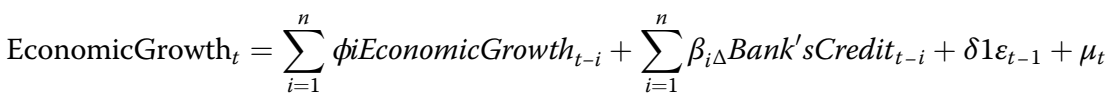

$$
\begin{aligned}
& \text { Bank }^{\prime} \text { SCredit }_{t}=\sum_{j=1}^{p} \phi j \text { Bank }^{\prime} \text { Credit }_{t-j}+\sum_{j=1}^{p} \beta_{j \Delta} \text { EconomicGrowth }_{t-1}+\delta 2 \varepsilon_{t-1}+\mu_{t}
\end{aligned}
$$

Where $\varepsilon_{\mathrm{t}-1}$ is error correction term.

The short term causality will be analyzed using WALD test and long run causality using Granger Error correction models.

From both cointegration test and Granger causality test it is confirm that there is no relationship between Bank deposits and economic growth but bank's credit and economic growth is integrated and from pairwise granger causality test it is concluded that causality runs from GDP or economic growth to Bank's credits so in order to see long term and short term effect of causality VECM model will be used for model no 2 because in that model variables are cointegrated.

The result of long run causality in Table 5 describes that both coefficients have negative sign which is good however result of GDPG cause BCPS shows that corresponding probability is significant at $5 \%$ level of significance which shows that there is long run causality running from economic growth to Bank's credit.

However the result of BCPS cause GDPG shows that corresponding probability is insignificant at $5 \%$ level of significance which shows that there is no long run causality running from Bank's credit to economic growth.

WALD test has been used to test short run causality between Bank's credit and GDP. Results are in Table 6.

The result shows that there is short run causality running from GDP to Bank's credit because $\mathrm{p}$ value is less than $5 \%$. However, there is no short run causality running from Bank's credit to GDP as p value is more than $5 \%$.

The estimated results accuracy has been validated by different diagnostic tests that are Test of serial correlation (LM), Heteroskedasticity Test and Normality Test (Jarque bera). All tests validated the estimated results and showed that there is no serial correlation in residuals, no heteroskedasticity and residuals are normally distributed. 
Table 7 Quandt-Andrews unknown breakpoint test

\begin{tabular}{lllllll}
\hline Break point test & Model no 1 & & Model no 2 & \\
\cline { 2 - 3 } & $\begin{array}{l}\text { Causality from bank } \\
\text { deposits to GDP }\end{array}$ & $\begin{array}{l}\text { Causality from GDP } \\
\text { to bank deposits }\end{array}$ & & $\begin{array}{l}\text { Causality from } \\
\text { bank credit to GDP }\end{array}$ & $\begin{array}{l}\text { Causality from } \\
\text { GDP to bank credit }\end{array}$ \\
\hline $\begin{array}{l}\text { Maximum } \\
\text { LR F-statistic (1989) }\end{array}$ & $1.108528(1.0000)$ & $0.408038(1.0000)$ & & $0.452622(0.9999)$ & $1.247246(0.9944)$ \\
$\begin{array}{l}\text { Maximum Wald } \\
\text { F-statistic (1989) }\end{array}$ & $1.108528(1.0000)$ & $0.408038(1.0000)$ & $0.452622(0.9999)$ & $1.247246(0.9944)$ \\
\hline
\end{tabular}

Null Hypothesis: No breakpoints within trimmed data

Note: probabilities calculated using Hansen's (1997) method

Number of breaks compared: 2

\section{Test for structural break}

Quandt-Andrews unknown breakpoint test has been used in order to test structural breaks within models, probabilities were calculated using Hansen's (1997) method. Results are in Table 7 which confirmed that there is no breakpoint within the data.

\section{Conclusions}

This study concludes that in Pakistan which is a developing country, two major activities of banking sector that are saving and lending don't have any long run or short run causality towards economic growth so the general consideration of positive impact of these activities on economic growth proved wrong in case of Pakistan however there is unidirectional causality running from GDP growth to credit provided by banking sector which shows that economic prosperity or economic growth will have a major impact on lending activities of banks meaning that demand following hypothesis is true for Pakistan in case of GDP and Bank's credit or we can say that growth led Bank's credit in Pakistan. There can be two reasons of this causal relationship.

1. Economic prosperity of the country will determine that whether country is good for investment so if goods will produce in country mean increase in GDP then small and medium enterprises and investor will take loans from banks for investment purpose so causality will run from GDP to bank's credit.

2. Second reason can be that if GDP growth will slow so people will be poor that's why they will take loans from banks for their personal use and not for investment purpose this can also be a reason of unidirectional causality from GDP growth to bank's lending activities rather than bidirectional relationship.

There might be other factors which influence economic growth of Pakistan more than banking sector these activities, which can be bank's profitability, human resource, technology, infrastructure and other sectors of the economy.

Government should make policies by considering the fact that there is no short term or long term causality running from banking activities to GDP growth however in short run and long run GDP growth affects bank's lending activities in Pakistan. So during high economic growth year central bank and private bank's management should introduce easy loans for businesses and industries and during poor economic growth years personal loan's new schemes should be introduce by banks. 


\section{Competing interests}

Author of the paper understand "Financial Innovation" Journal Policy on declaration of interests and declare that she has no competing interests.

\section{Authors' contributions}

I am the only author of this research Paper.

\section{Authors' information}

Saba Mushtaq is PhD scholar at Department of Business Administration (Karachi University Business School), University of Karachi, Karachi, Pakistan

\section{Acknowledgements}

The author is grateful to her Father Rana Mushtaq Ahmed, Mother Rukhsana Begum and siblings (Zohaib, Rida, Saqlain and Faiza) for their cooperation, support and encouragement.

Received: 8 February 2016 Accepted: 27 April 2016

Published online: 10 June 2016

\section{References}

Alkhuzaim W (2014) Degree of Financial Development and Economic Growth in Qatar: Cointegration and Causality Analysis. Int J Econ Finance 6(6):57-69

Aurangzeb (2012) Contribution of banking sector in economic growth: a case of Pakistan. Econ Finance Rev 2(6):45-54

A Awdeh (2012) Banking sector development and economic growth in Lebanon. Int Res J Finance Econ (100):53-62

Babatunde JH et al (2013) The impact of commercial banks on Malaysian economic development. Int J Mod Bus 1(3):20-31

Caporale GM et al (2009) Financial Development and Economic Growth: Evidence from Ten new EU members. German Inst Econ Res discussion paper no 940.

Emecheta BC, Ibe RC (2014) Impact of bank credit on economic growth in Nigeria: application of reduced vector autoregressive (VAR) technique. Eur J Account Auditing Finance Res 2(9):11-21

Granger CW (1969) Investigating causal relationships by economic models and cross spectral models. Econometrica 37:424-438

Iwedi M et al (2015) Bank domestic credits and economic growth nexus in Nigeria (1980-2013). Int J Finance Accounting 4(5):236-244

Johansen S, Juselius K (1990) Maximum likelihood estimation and inference on cointegration with applications to the demand for money. Oxf Bull Econ Stat 52(2):169-210

Korkmaz S (2015) Impact of bank credits on Economic growth and inflation". J Appl Finance Banking 5(01):57-69

Kumar S, Chauhan S (2015) Impact of Commercial Deposit in Banks with GDP in context with Pradhan Mantri Jan Dhan Yojna. BVIMSR's J Manage Res 7(1):53-59

Liang H-Y, Reichert A (2006) The Relationship between economic growth and Banking sector development. Banks Bank Syst 1(2):19-35

Marshal I et al (2015) Causality modeling of the banking sector credits and economic growth in Nigeria. IIARD Int J Banking Finace Res 1(7):1-12

Nwakanma PC et al (2014) Bank credits to Private sector : Potency and Relevance in Nigeria's Economic Growth Process. Account Finance Res 3(02):23-35

Obradovic S, Grbic M (2015) Causality relationship between financial intermediation by banks and economic growth: Evidence from Serbia. Prague Econ Pap 24(01):60-72

Onuorah, AC-C, Ozurumba BA (2013) Bank Credits: An Aid to Economic Growth in Nigeria. Inf Know Manage 3(3):41-5

Osman E GA (2014) The impact of private sector credit on Saudi Arabia Economic Growth (GDP): An Econometrics model using (ARDL) Approach to Cointegration. Am Int J Soc Sci 3(6):109-117

Patrick H (1966) Financial Development and Economic Growth in Underdeveloped Countries. Economic Development and Cultural Change, 174-189

Sharma D, Ranga M (2014) Impact of saving deposits of commercial banks on GDP. Indian J Appl Res 4(9):95-97

Tahir M (2008) An investigation of the effectiveness of financial development in Pakistan. Lahore J Econ 13(2(winter)):27-44

World development indicators(WDI), World Bank 